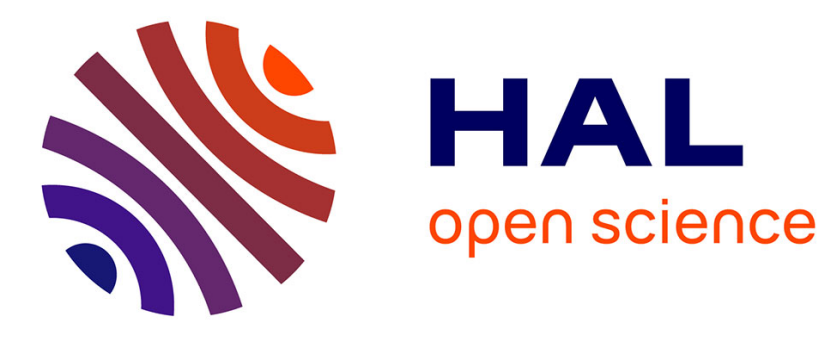

\title{
Effects of intense agricultural practices on heterotrophic processes in streams
}

Christophe Piscart, Romuald Genoel, Sylvain Dolédec, Eric Chauvet, Pierre Marmonier

\section{- To cite this version:}

Christophe Piscart, Romuald Genoel, Sylvain Dolédec, Eric Chauvet, Pierre Marmonier. Effects of intense agricultural practices on heterotrophic processes in streams. Environmental Pollution, 2009, 157, pp.1011-1018. 10.1016/j.envpol.2008.10.010 . hal-00870740

\section{HAL Id: hal-00870740 \\ https://hal.science/hal-00870740}

Submitted on 8 Oct 2013

HAL is a multi-disciplinary open access archive for the deposit and dissemination of scientific research documents, whether they are published or not. The documents may come from teaching and research institutions in France or abroad, or from public or private research centers.
L'archive ouverte pluridisciplinaire HAL, est destinée au dépôt et à la diffusion de documents scientifiques de niveau recherche, publiés ou non, émanant des établissements d'enseignement et de recherche français ou étrangers, des laboratoires publics ou privés. 


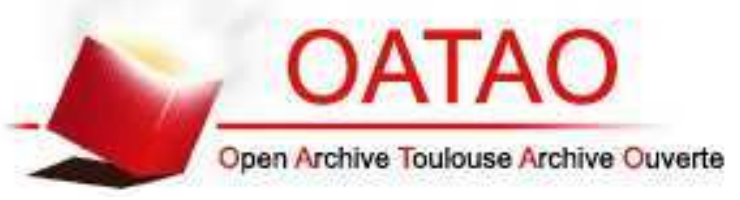

\section{Open Archive TOULOUSE Archive Ouverte (OATAO)}

OATAO is an open access repository that collects the work of Toulouse researchers and makes it freely available over the web where possible.

This is an author-deposited version published in : http://oatao.univ-toulouse.fr/ Eprints ID : 9675

To link to this article : DOI:10.1016/j.envpol.2008.10.010

URL : http://dx.doi.org/10.1016/j.envpol.2008.10.010

To cite this version : Piscart, Christophe and Genoel, Romuald and Doledec, Sylvain and Chauvet, Eric and Marmonier, Pierre. Effects of intense agricultural practices on heterotrophic processes in streams. (2009) Environmental Pollution, vol. 157 ( $\left.\mathrm{n}^{\circ} 3\right)$. pp. 10111018. ISSN 0269-7491

Any correspondance concerning this service should be sent to the repository administrator: staff-oatao@ listes-diff.inp-toulouse.fr 


\title{
Effects of intense agricultural practices on heterotrophic processes in streams
}

\author{
Christophe Piscart $^{\mathrm{a}, \mathrm{b}, *}$, Romuald Genoel ${ }^{\mathrm{b}}$, Sylvain Doledec ${ }^{\mathrm{a}}$, Eric Chauvet ${ }^{\mathrm{c}}$, Pierre Marmonier $^{\mathrm{a}, \mathrm{b}}$ \\ ${ }^{a}$ Université Claude Bernard Lyon 1 - Laboratoire d'Ecologie des Hydrosystèmes Fluviaux - UMR CNRS 5023 - Campus Doua, 43 Bd du 11 Novembre 1918 , \\ 69622 Villeurbanne Cedex, France \\ ${ }^{\mathrm{b}}$ Université de Rennes 1 - UMR CNRS ECOBIO 6553 - Campus Beaulieu, 263 Av. du Général Leclerc, 35042 Rennes Cedex, France \\ ${ }^{c}$ Université Paul Sabatier de Toulouse - Laboratoire EcoLab - UMR CNRS 5245, 29 rue Jeanne Marvig, 31055 Toulouse Cedex 4, France
}

This study highlights the consequences of intensive agricultural practices on heterotrophic processes in streams along a strong gradient of perturbation.

Keywords:

Land use

Nutrient

Leaf litter breakdown

Macroinvertebrates

Hydrolasic activity

\begin{abstract}
A B S T R A C T
In developed countries, changes in agriculture practices have greatly accelerated the degradation of the landscape and the functioning of adjacent aquatic ecosystems. Such alteration can in turn impair the services provided by aquatic ecosystems, namely the decomposition of organic matter, a key process in most small streams. To study this alteration, we recorded three measures of heterotrophic activity corresponding to microbial hydrolasic activity (FDA hydrolysis) and leaf litter breakdown rates with $\left(k_{c}\right)$ and without invertebrates $\left(k_{\mathrm{f}}\right)$ along a gradient of contrasted agricultural pressures. Hydrolasic activity and $k_{\mathrm{f}}$ reflect local/microhabitat conditions (i.e. nutrient concentrations and organic matter content of the sediment) but not land use while $k_{\mathrm{c}}$ reflects land-use conditions. $k_{\mathrm{c}}$, which is positively correlated with the biomass of Gammaridae, significantly decreased with increasing agricultural pressure, contrary to the taxonomic richness and biomass of Trichoptera and Plecoptera. Gammaridae may thus be considered a key species for organic matter recycling in agriculture-impacted streams.
\end{abstract}

\section{Introduction}

In most developed countries, changes in agriculture practices (type of cultivated crops, increase in nutrient loads) have greatly accelerated the alteration of the landscape (removing hedgerow, increasing field size) in the last 20-30 years. The contribution of agriculture to nutrient enrichment in rivers has been widely studied (Meybeck, 1982; Vitousek et al., 1997). Increases in nutrient contents, mostly nitrogen (Arheimer and Liden, 2000; Castillo et al., 2000; Goolsby et al., 2000; Huryn et al., 2002), phosphorus (Fisher et al., 2000; Bramley and Roth, 2002), and dissolved organic carbon (Ometo et al., 2000; Findlay et al., 2001) are among the most commonly reported agriculture impacts on streams.

The main drawbacks with the use of physico-chemical parameters for assessing agricultural impacts is their high temporal variability linked to both the hydrological cycle and agricultural practices (Randall and Mulla, 2001). In contrast, ecologists have

\footnotetext{
* Corresponding author. Université Claude Bernard Lyon 1 - Laboratoire d'Ecologie des Hydrosystèmes Fluviaux - UMR CNRS 5023 - Campus Doua, 43 Bd du 11 Novembre 1918, 69622 Villeurbanne Cedex, France. Tel.: +33 4724482 69; fax: +33472431523.

E-mail address: christophe.piscart@univ-lyon1.fr (C. Piscart).
}

long recognized that aquatic flora and fauna have the capacity to reveal a source of perturbation even if this source does not discharge pollutants, a feat impossible by chemical analysis alone (e.g. Hynes, 1960; Ometo et al., 2000; Townsend et al., 2004). For example, several studies have pointed out changes in assemblage structure and composition for both invertebrates and fishes following landscape modifications (see a review in Harding et al., 1998; Allan, 2004; Dolédec et al., 2006; Hagen et al., 2006), but changes in their role in ecosystem processes are rarely considered. Different microbial activities (Ainsworth and Goulder, 2000; Amann, 2000; Eisman and Montuelle, 1999; Montuelle and Volat, 1998) and biofilm primary production (e.g. for agriculture Corkum, 1996; Young and Huryn, 1999) have been shown to be efficient descriptors of river health and function. In recent years, there has been a growing interest in the use of leaf litter breakdown to assess the functional integrity of stream ecosystems (Gessner and Chauvet, 2002; Lecerf et al., 2006), but the effect of agriculture on heterotrophic processes has been evaluated only within a low range of perturbation (Young and Huryn, 1999; Hagen et al., 2006).

The originality of our study lies in the wide range of agriculture impacts considered and the combination of different methods to evaluate heterotrophic activities. Twelve sites were selected in three rivers with varying land uses, from forested areas (considered as a reference) to extensively and intensively cultivated areas. Three 
different measures of heterotrophic processes were used: sediment-associated hydrolasic activity, particulate organic matter breakdown resulting from either microbial activities or from both microbe and invertebrate activities. We hypothesized that agriculture (1) should increase microbial heterotrophic activities through an increase in nutrient availability for both sediment microbial activities (Claret et al., 2001) and litter breakdown (Suberkropp and Chauvet, 1995), but (2) should decrease shredder contribution to litter breakdown due to deleterious effects on invertebrates (Huryn et al., 2002; Lecerf et al., 2006). The invertebrate density, biomass and type of functional feeding group were considered in both the litter bags and the natural benthic litter. We hypothesized that rates of litter breakdown were linked to (3) the diversity of the invertebrate assemblages (Huryn et al., 2002) and (4) to the abundance and biomass of shredders (Benfield and Webster, 1985; Lecerf et al., 2006).

\section{Material and methods}

2.1. Study sites

The study area was located within the Long Term Socio-Ecological Research site of Pleine-Fougères (Brittany, Western France, Fig. 1). It consisted of a patchy landscape with forests, pastures, crop cultures and farming zones, exhibiting a wide gradient of agricultural pressure (Burel et al., 2003). Twelve sites were selected in four streams with similar riparian vegetation (with trees on one bank and grassland on the other, Table 1) and instream characteristics (e.g. local water velocity, discharge and geomorphology, Tables 1 and 2), but differing agricultural intensity in the catchment. Four sites were located in a stream receiving waste waters from

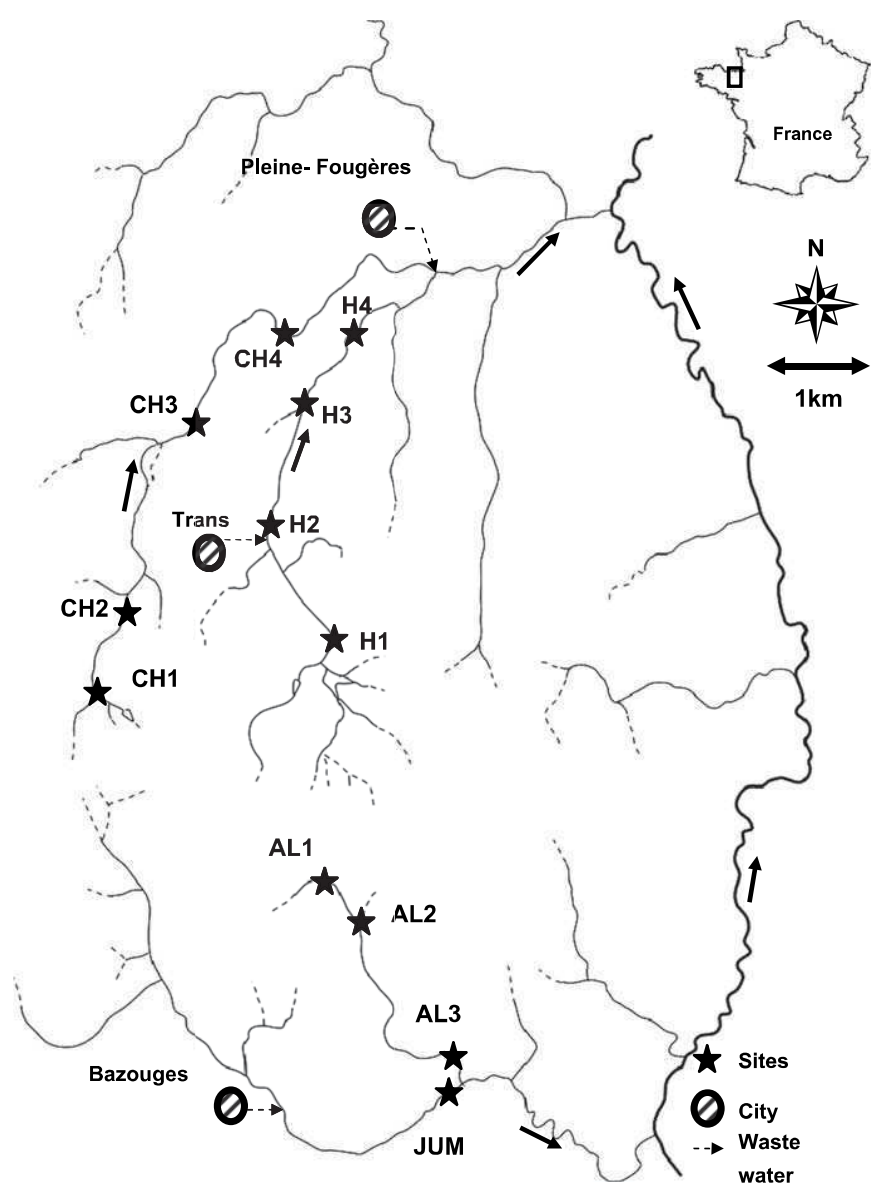

Fig. 1. Study area with the location of villages (hatched), waste water outflows (dotted arrows) and the 12 sampling sites (stars) located in four streams ("Petit Hermitage" stream: H1, H2, H3, H4; "Chênelais" stream: $\mathrm{CH} 1, \mathrm{CH} 2, \mathrm{CH} 3, \mathrm{CH} 4$; "Aleçon" stream: AL1, AL2, AL3; "Jumelière" stream: JUM). a village (580 inhabitants) and industrial farming (chickens and cows). The upstream site was located above the waste water outflow in a forest (Villecartier) and was used as a reference site ("Petit Hermitage" stream: H1 in Fig. 1). The three other sites were located downstream the waste water outflow (H2, H3, H4 in Fig. 1). Four sites were located in a stream subjected to increasing agricultural pressure from up- to downstream ("Chênelais" stream: $\mathrm{CH} 1, \mathrm{CH} 2, \mathrm{CH} 3, \mathrm{CH} 4$ in Fig. 1) and three sites were located in a stream only affected by a gradient of increasing agricultural pressure [along up- to downstream or] ("Aleçon" stream: AL1, AL2, AL3 in Fig. 1). Finally, one site was located downstream of the waste water outflow of a town (1840 inhabitants) in an area dominated by crop fields and industrial cow and pig farming ("Jumelière" stream: JUM in Fig. 1). In the study region, the level of physico-chemical of streams is not directly related to their overall catchment land use (Sarriquet et al., 2006) because of the nutrient retention capacity of riparian wetlands and hedgerows (Montreuil and Mérot, 2006). We thus determined the stream water chemistry during a four-month period encompassing the leaf decomposition experiment and invertebrate sampling period.

Three water samples were collected at each site every two weeks from February to May 2005 and analyzed the same day. Water temperature, conductivity (LF92, WTW' ${ }^{\mathrm{TM}}$, Weilheim, Germany), $\mathrm{pH}$, and dissolved oxygen content (HQ20, $\mathrm{HACH}^{\mathrm{TM}}$ Dusseldorf, Germany) were measured in the field. In the laboratory, filtered-water samples (GF/C, $1.2 \mu \mathrm{m}$ pore size, Whatman ${ }^{\mathrm{TM}}$, Maidstone, UK) were analyzed by colorimetric methods: molybdate-antimony for soluble reactive phosphorus (P-SRP; Murphy and Riley, 1962), indophenol blue for ammonium (N-NH$+\mathrm{N}_{4}^{+}$; Rossum and Villaruz, 1963), diazotation for nitrite $\left(\mathrm{N}_{-} \mathrm{NO}_{2}^{-}\right.$; Barnes and Kollard, 1951) and after a reduction to nitrite by activated cadmium followed by nitrite titration for nitrate $\left(\mathrm{N}-\mathrm{NO}_{3}^{--}\right.$; APHA, 1976).

\subsection{Microbial activity in the sediment}

Microbial activity in the sediment was estimated using the fluorescein diacetate (FDA) hydrolysis method (Schnurer and Rosswall, 1982; Fontvieille et al., 1992), where $0.1 \mathrm{ml}$ of FDA and $3 \mathrm{ml}$ of phosphate buffer $(\mathrm{pH}=7.6)$ were added to $1-2 \mathrm{~g}$ of wet fine sediment (grain size $<200 \mu \mathrm{m}$ ) and incubated for $30-45 \mathrm{~min}$ at field temperature (Battin, 1997). Biological activity was stopped using $3 \mathrm{ml}$ of pure acetone on ice. Supernatants were filtered with $0.45 \mu \mathrm{m}$ cellulose membrane, rapidly frosted at $-20^{\circ} \mathrm{C}$ and kept frozen until analysis. Fluorescein concentration was calculated from the optical density of the filtered supernatant measured at $490 \mathrm{~nm}$. The sediments used were dried during $24 \mathrm{~h}$ at $105^{\circ} \mathrm{C}$ and total organic matter (TOM) concentration was measured by loss on ignition of dried sediment ( $4 \mathrm{~h}$ at $550{ }^{\circ} \mathrm{C}$; Bretschhko and Leichtfried, 1988). Results were finally expressed as $\mu$ mole of hydrolysed FDA per gram of dry sediment per hour or per gram of TOM per hour, the highest value corresponding to the highest microbial activity.

\subsection{Leaf litter decomposition and invertebrate sampling}

The litter-bag method (Chauvet, 1987; Boulton and Boon, 1991) was used to assess breakdown rate along the gradient of agricultural impact. Freshly fallen leaves of Fagus sylvatica, the dominant tree species in Northern Brittany woodlands and riparian forests, were collected in December 2004 from forests adjacent to the study sites. About $4( \pm 0.05) \mathrm{g}$ of air-dried leaves were enclosed in coarse $(6 \mathrm{~mm}$ mesh, $15 \times 15 \mathrm{~cm}$ plastic bags $)$ and $2( \pm 0.05) \mathrm{g}$ in fine $(0.5 \mathrm{~mm}$ mesh, $15 \times 8 \mathrm{~cm}$ nylon bags $)$ mesh bags closed in a quadratic shape. The coarse mesh allowed large shredders (such as Gammaridae and Limnephilidae) to enter the bag and feed on leaves, whereas fine mesh excluded most of the invertebrates without interfering with microbial colonization (Boulton and Boon, 1991). Fifteen bags per site were firmly tethered on the 17th of February 2005 to steel pegs placed within shallow riffles with similar current velocities (Table 1). Three bags of each type were collected at each site after $10,24,38,52$, and 66 days of immersion. To reduce invertebrate loss, a Surber net $(0.5 \mathrm{~mm}$ mesh size) was placed downstream during leaf bag removal to collect dislodged animals only. Upon retrieval, the leaves were washed individually to remove sand, exogenous organic matter and invertebrates. The remaining leaf material from both types of bags was dried at $105^{\circ} \mathrm{C}$ for $24 \mathrm{~h}$ and weighed to the nearest $\mathrm{mg}$. Three control litter bags were used to estimate the initial dry mass of leaf litter after a short immersion time and drying at $105^{\circ} \mathrm{C}$ for $24 \mathrm{~h}$. Exponential litter breakdown rate $(k)$ was calculated using the relationship,

$W_{t}=W_{\mathrm{i}} e^{-k t}$

where $W_{t}$ is the leaf dry mass remaining at the time $t$ and $W_{\mathrm{i}}$ the leaf dry mass at the initial time (Petersen and Cummins, 1974). Calculations were performed separately for fine $\left(k_{\mathrm{f}}\right)$ and coarse mesh $\left(k_{\mathrm{c}}\right)$ bags. Invertebrates were preserved with $5 \%$ formaldehyde until identification. Invertebrates from coarse mesh bags were identified to species or genus except Nematoda, Oligochaeta, Hydracarina (not identified further), and most Diptera (to the family), counted, and preserved in $70 \%$ ethanol. The biomass of dominant group of shredders (i.e. Gammaridae, Trichoptera and Plecoptera) was determined separately from the other invertebrates by weighing dried $\left(105^{\circ} \mathrm{C}, 24 \mathrm{~h}\right)$ animals to the nearest $0.1 \mathrm{mg}$.

To compare invertebrate assemblages in litter bags and in the streams, four invertebrate samples were collected at each site in benthic litter on the 4th and 5th April 2005. The litter was removed to a depth of about $5 \mathrm{~cm}$ using a Surber net 
Table 1

Environmental characteristics of the 12 sites located on the "Petit Hermitage" (H1H4), "Chênelais" stream (CH1-CH4), and "Aleçon-Jumelière" (AL1-JUM) streams. Riparian vegetation directly surrounding the stations on right and left banks is noted as forest $(F)$, hedgerow $(H)$, or grassland $(G)$. Distance to waste water outflows from villages or industrial farming is indicated when applicable.

\begin{tabular}{lllll}
\hline Site & $\begin{array}{l}\text { Stream } \\
\text { order }\end{array}$ & $\begin{array}{l}\text { Water velocity } \\
\left(\mathrm{m} \mathrm{s}^{-1}\right)\end{array}$ & $\begin{array}{l}\text { Riparian } \\
\text { vegetation }\end{array}$ & $\begin{array}{l}\text { Distance to waste } \\
\text { water outflows }(\mathrm{km})\end{array}$ \\
\hline $\mathrm{H} 1$ & 2 & $0.25 \pm 0.09$ & $\mathrm{~F}+\mathrm{G}$ & - \\
$\mathrm{H} 2$ & 2 & $0.33 \pm 0.04$ & $\mathrm{H}+\mathrm{G}$ & 0.3 \\
$\mathrm{H} 3$ & 2 & $0.42 \pm 0.07$ & $\mathrm{G}+\mathrm{H}$ & 1.4 \\
$\mathrm{H} 4$ & 2 & $0.40 \pm 0.07$ & $\mathrm{G}+\mathrm{H}$ & 2.7 \\
$\mathrm{CH} 1$ & 2 & $0.23 \pm 0.04$ & $\mathrm{H}+\mathrm{G}$ & - \\
$\mathrm{CH} 2$ & 2 & $0.18 \pm 0.08$ & $\mathrm{H}+\mathrm{G}$ & - \\
$\mathrm{CH} 3$ & 3 & $0.23 \pm 0.07$ & $\mathrm{G}+\mathrm{H}$ & - \\
$\mathrm{CH} 4$ & 3 & $0.43 \pm 0.11$ & $\mathrm{G}+\mathrm{H}$ & - \\
$\mathrm{AL} 1$ & 1 & $0.26 \pm 0.11$ & $\mathrm{G}+\mathrm{H}$ & - \\
$\mathrm{AL2}$ & 1 & $0.23 \pm 0.11$ & $\mathrm{G}+\mathrm{H}$ & - \\
$\mathrm{AL} 3$ & 2 & $0.46 \pm 0.16$ & $\mathrm{H}+\mathrm{G}$ & - \\
$\mathrm{JUM}$ & 3 & $0.24 \pm 0.14$ & $\mathrm{G}+\mathrm{H}$ & 2.4 \\
\hline
\end{tabular}

$\left(0.05 \mathrm{~m}^{2}, 0.5 \mathrm{~mm}\right.$ mesh size). Samples were fixed with $5 \%$ formaldehyde in the field. In the laboratory, organisms were sorted, identified at the same taxonomic level as invertebrates collected in the leaf litter bags, counted, and preserved in $70 \%$ ethanol.

To characterize invertebrate assemblages in leaf litter bags and to compare them with instream assemblages (Surber samples), taxonomic richness, abundance, and Simpson dominance index (see Magurran, 1988 for details) were calculated for each sample considering the total fauna list on one hand and shredders only (according to Tachet et al., 2000) on another hand.

\subsection{Statistical analysis}

We performed a PCA on the average nutrient contents (nitrates, nitrites, ammonium and soluble reactive phosphorus). Since the first two PCA axes delivered most of the variability (i.e. $74.6 \%$ ), we used these axes to classify sites by cluster analysis (Euclidean distance and Ward's aggregation method) on the first two axes of a PCA on the average nutrient contents (nitrates, nitrites, ammonium and soluble reactive phosphorus). This enabled a global grouping of sites along the gradient of agricultural practices and resulted in a land-use typology. The significance of the overall difference (between-group variances) was tested against simulated values obtained after 1000 permutations of the rows of the water chemistry table (Romesburg, 1985). Analyses were performed using ade4 library implemented in R freeware (e.g. Ihaka and Gentleman, 1996).

Leaf breakdown rates were determined by non-linear regression (Petersen and Cummins, 1974). We used the Spearman's Rank correlation to highlight the relationships between land-use types and heterotrophic processes (hydrolasic activity, water chemistry, leaf litter breakdown rates $k_{\mathrm{c}}$ and $k_{\mathrm{f}}$ ) and faunal assemblages (biocenotic indices and biomass of invertebrates) in leaf litter bags and in Surber net samples.
Kruskal-Wallis tests were performed to highlight differences among land-use types for hydrolasic activity and invertebrate abundance in litter bags. Changes between two pair-wise comparisons were investigated through a post-hoc analysis based on multiple comparison tests (Siegel and Castellan, 1988) using procedures from Statistica 7.1 (StatSoft, 2001)

\section{Results}

\subsection{Water chemistry and microbial activity in sediment}

According to cluster analysis based on the average nutrient contents, sites were classified into four land-use groupings. A first grouping (Fig. 2) included the four sites downstream of waste water outflows (JUM, H2, H3, H4) which had high $\mathrm{N}-\mathrm{NH}_{4}^{+}, \mathrm{N}_{-} \mathrm{NO}_{2}^{-}$, and $\mathrm{P}-$ SRP concentrations (Table 2). The second group incorporated sites not directly influenced by waste waters and could be divided into three other groups according to the intensity of agricultural activities in the watershed (Fig. 2): (i) the forested site with low nutrient concentrations (H1), (ii) the four sites located in traditional hedged farming area (AL1, AL2, CH1, CH2) with intermediate nutrient concentrations, and (iii) the three sites located in the more intensively exploited area $(\mathrm{CH} 3, \mathrm{CH} 4, \mathrm{AL} 3)$ with high nitrate and intermediate $\mathrm{N}-\mathrm{NH}_{4}^{+}, \mathrm{N}-\mathrm{NO}_{2}^{-}$, and P-SRP concentrations (Table 2).

Between-class PCA performed on the nutrient parameters $(\mathrm{N}$ $\mathrm{NH}_{4}^{+}, \mathrm{N}-\mathrm{NO}_{2}^{-}, \mathrm{N}-\mathrm{NO}_{3}^{-}$and $\mathrm{P}-\mathrm{SRP}$ ) showed that site groupings (above) explained significantly more variability (observed variability between site groupings $=34.6 \%$, simulated $p$-value $<0.001$ ) than stream groupings (observed variability between streams $=11.6 \%$, simulated $p$-value $<0.001$ ) and was further used as a proxy for land uses. Our final land-use typology thus resulted into four groupings that combine all anthropogenic disturbances at the catchment scale (gradients in agriculture activities and local enrichment in nutrients): forested area (noted $\mathrm{F}$ in Table 2), traditional hedged farming (HF, Table 2), intensive agriculture (IA, Table 2), and intensive agriculture with waste water outflows (IA $+\mathrm{WW}$, Table 2$)$.

\subsection{Hydrolasic activity}

FDA hydrolysis microbial activity ranged from 0.004 to $0.323 \mu \mathrm{M} / \mathrm{g} / \mathrm{h}$ when reported as sediment dry mass. It was significantly and positively correlated with the total organic matter content of the sediment $(r=0.776 ; p<0.003$, Fig. 3a). To take into account the local effect of organic matter content, hydrolasic microbial activity was also reported as organic matter dry mass. It ranged from 0.33 to $6.58 \mu \mathrm{M} / \mathrm{gOM} / \mathrm{h}$, but did neither vary

Table 2

Water chemical characteristics (mean $\pm \mathrm{SD}$ ) of the 12 studied sites and groups of sites taken from a cluster analysis (last line in bold), with $\mathrm{F}=\mathrm{Forest}$; $\mathrm{HF}=\mathrm{Hedged} \mathrm{Farmland;}$ $\mathrm{IA}=$ Intensive Agriculture; IA $+\mathrm{WW}=$ Intensive Agriculture + Waste Water

\begin{tabular}{|c|c|c|c|c|c|c|c|c|}
\hline & Temperature $\left({ }^{\circ} \mathrm{C}\right)$ & Dissolved $\mathrm{O}_{2}\left(\mathrm{mg} \mathrm{l}^{-1}\right)$ & $\mathrm{pH}$ & Conductivity $\left(\mu \mathrm{S} \mathrm{cm}^{-1}\right)$ & $\mathrm{N}-\mathrm{NO}_{3}^{-}\left(\mu \mathrm{gNI}^{-1}\right)$ & $\mathrm{N}-\mathrm{NO}_{2}^{-}\left(\mu \mathrm{gNI}^{-1}\right)$ & $\mathrm{N}-\mathrm{NH}_{4}^{+}\left(\mu \mathrm{gNI}^{-1}\right)$ & $\overline{P-S R P}\left(\mu g^{-1} 1^{-1}\right)$ \\
\hline$\overline{\mathrm{F}(\mathrm{H} 1)}$ & $8.7 \pm 3.4$ & $10.9 \pm 1.2$ & $7.0 \pm 0.4$ & $159 \pm 5$ & $510 \pm 19$ & $\mathbf{1 0} \pm \mathbf{8}$ & $49 \pm 18$ & $19 \pm 8$ \\
\hline $\mathrm{CH} 1$ & $8.2 \pm 3.3$ & $10.5 \pm 1.5$ & $6.9 \pm 0.2$ & $326 \pm 16$ & $2820 \pm 173$ & $23 \pm 6$ & $80 \pm 43$ & $29 \pm 15$ \\
\hline $\mathrm{CH} 2$ & $8.1 \pm 3.1$ & $10.7 \pm 1.4$ & $6.9 \pm 0.3$ & $331 \pm 17$ & $3070 \pm 164$ & $24 \pm 7$ & $87 \pm 50$ & $36 \pm 20$ \\
\hline AL1 & $8.2 \pm 2.9$ & $11.3 \pm 1.3$ & $7.1 \pm 0.3$ & $261 \pm 7$ & $2720 \pm 127$ & $17 \pm 6$ & $86 \pm 66$ & $40 \pm 16$ \\
\hline AL2 & $8.2 \pm 3.1$ & $10.6 \pm 1.5$ & $6.9 \pm 0.4$ & $271 \pm 13$ & $3710 \pm 193$ & $18 \pm 9$ & $91 \pm 50$ & $30 \pm 11$ \\
\hline $\mathrm{HF}$ & $8.2 \pm 3.0$ & $10.8 \pm 1.4$ & $6.9 \pm 0.3$ & $297 \pm 34$ & $3080 \pm 167$ & $20 \pm 8$ & $86 \pm 52$ & $34 \pm 16$ \\
\hline $\mathrm{CH} 3$ & $8.5 \pm 3.3$ & $11.4 \pm 1.4$ & $7.4 \pm 0.3$ & $349 \pm 16$ & $4080 \pm 195$ & $18 \pm 6$ & $50 \pm 20$ & $33 \pm 10$ \\
\hline $\mathrm{CH} 4$ & $9.1 \pm 2.9$ & $11.1 \pm 1.2$ & $7.4 \pm 0.4$ & $391 \pm 14$ & $4920 \pm 157$ & $22 \pm 5$ & $62 \pm 11$ & $28 \pm 6$ \\
\hline AL3 & $8.4 \pm 2.8$ & $11.8 \pm 1.6$ & $7.0 \pm 0.4$ & $303 \pm 13$ & $4900 \pm 189$ & $12 \pm 6$ & $65 \pm 38$ & $32 \pm 11$ \\
\hline IA & $\mathbf{8 . 5} \pm \mathbf{3 . 0}$ & $11.5 \pm 1.4$ & $7.3 \pm \mathbf{0 . 4}$ & $349 \pm 40$ & $4630 \pm 182$ & $17 \pm 7$ & $59 \pm 26$ & $\mathbf{3 1} \pm \mathbf{9}$ \\
\hline $\mathrm{H} 2$ & $8.8 \pm 3.2$ & $10.7 \pm 1.3$ & $7.0 \pm 0.3$ & $298 \pm 34$ & $2770 \pm 117$ & $39 \pm 7$ & $320 \pm 136$ & $57 \pm 23$ \\
\hline H3 & $8.5 \pm 3.3$ & $11.7 \pm 1.3$ & $7.3 \pm 0.2$ & $300 \pm 33$ & $3350 \pm 184$ & $38 \pm 8$ & $146 \pm 92$ & $48 \pm 19$ \\
\hline $\mathrm{H} 4$ & $8.6 \pm 3.2$ & $11.0 \pm 1.3$ & $7.4 \pm 0.2$ & $321 \pm 39$ & $3300 \pm 144$ & $33 \pm 8$ & $116 \pm 54$ & $46 \pm 13$ \\
\hline JUM & $8.7 \pm 3.0$ & $11.8 \pm 1.8$ & $7.1 \pm 0.4$ & $344 \pm 21$ & $6490 \pm 225$ & $42 \pm 14$ & $97 \pm 83$ & $95 \pm 55$ \\
\hline $\mathrm{IA}+\mathrm{WW}$ & $8.7 \pm 3.1$ & $11.1 \pm 1.5$ & $7.2 \pm 0.3$ & $316 \pm 36$ & $3980 \pm 224$ & $38 \pm 10$ & $170 \pm 129$ & $61 \pm 37$ \\
\hline
\end{tabular}




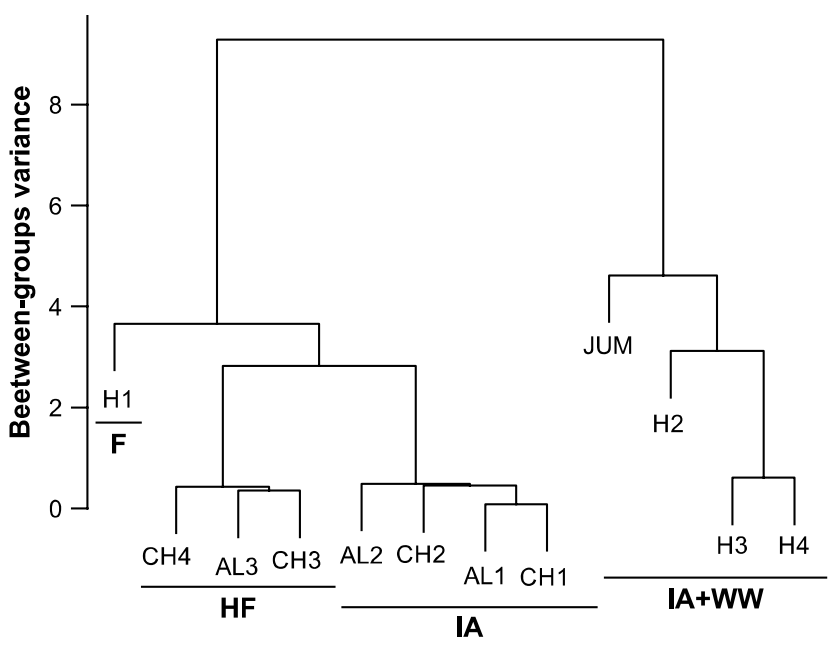

Fig. 2. Result of a cluster analysis performed on the first two axes of a PCA of the average nutrient content of each site using Ward's agglomerative method and the resulting classification by land-use type $(\mathrm{F}=$ Forest; $\mathrm{HF}=$ Hedged farmland $\mathrm{IA}=$ Intensive agriculture; IA $+\mathrm{WW}=$ Intensive agriculture plus waste water).

significantly along the upstream-downstream gradient (data not shown), nor according to the types of stations ( $r=0.194 ; p=0.546$; Fig. $3 b)$ and nitrate concentrations $(r=-0.364 ; p=0.245)$. However, hydrolasic microbial activity was significantly and positively correlated with $\mathrm{N}_{-} \mathrm{NH}_{4}^{+}(r=0.594 ; p=0.041), \quad \mathrm{N}-\mathrm{NO}_{2}^{-}$ $(r=0.594 ; p=0.041)$, and P-SRP concentrations $(r=0.622$; $p=0.031$ ).

\subsection{Litter breakdown due to microbial activity}

Leaf litter breakdown rate in fine mesh bags $\left(k_{\mathrm{f}}\right)$ was negatively correlated with $\mathrm{N}-\mathrm{NH}_{4}^{+}(r=-0.801 ; p=0.002), \mathrm{N}^{-} \mathrm{NO}_{2}^{-}(r=-0.648$;
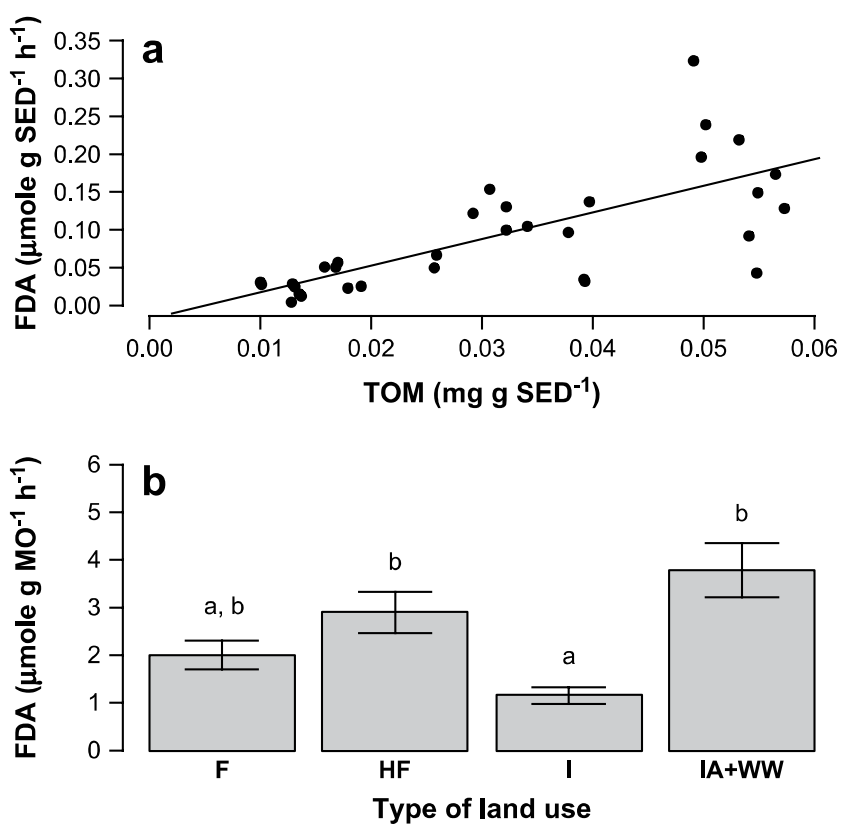

Fig. 3. (a) Relationship between hydrolasic microbial activity (FDA hydrolysis reported per gram of dry sediment per hour) and the total organic matter content of the sediment ( $\mathrm{mg}$ TOM per gram of dry sediment) $\left(R^{2}=0.51, y=3.34 x-0.01, p<3.10^{-6}\right)$. (b) Changes in hydrolasic microbial activity (mean $\pm 95 \%$ SE, expressed in FDA hydrolysis per gram of TOM per hour) according to the four types of land use $(\mathrm{F}=$ Forest; $\mathrm{HF}=$ Hedged farmland; $\mathrm{IA}=$ Intensive agriculture; $\mathrm{IA}+\mathrm{WW}=$ Intensive agriculture plus waste water). For each grouping, significant between-type differences (multiple comparison tests following the Kruskal-Wallis test) in hydrolasic microbial activities are indicated by different letters.
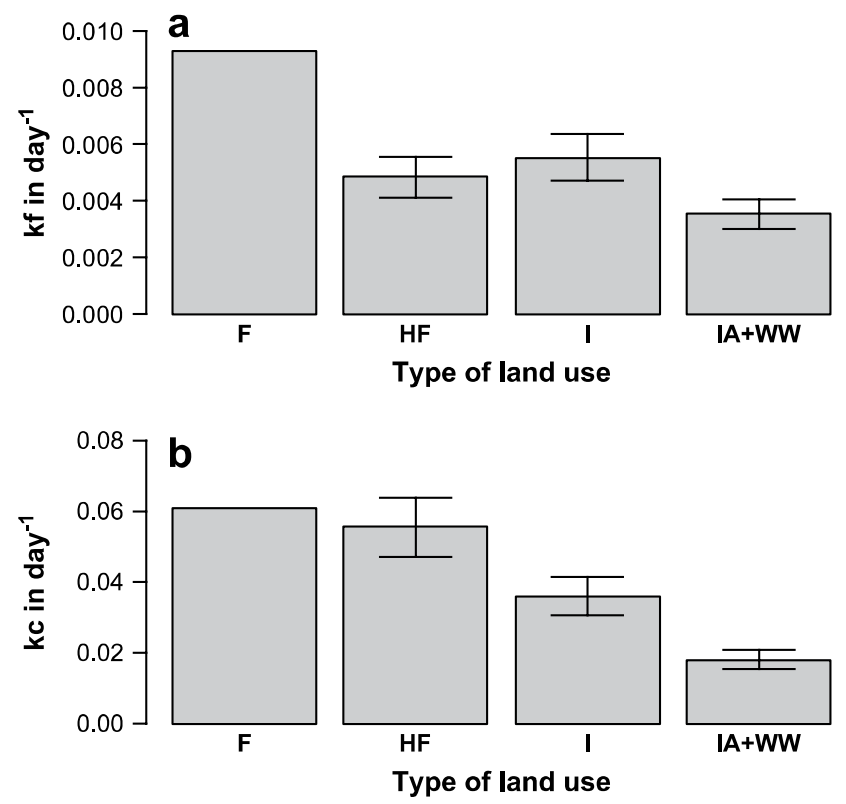

Fig. 4. Mean values $( \pm \mathrm{SE})$ of leaf litter breakdown rates in fine $\left(k_{\mathrm{f}}\right)$ and coarse $\left(k_{\mathrm{c}}\right)$ mesh bags in the four land-use groupings ( $\mathrm{F}=$ Forest; $\mathrm{HF}=$ Hedged farmland; $\mathrm{IA}=$ Intensive agriculture; IA $+\mathrm{WW}=$ Intensive agriculture plus waste water).

$p=0.023)$ and P-SRP $(r=-0.676 ; p=0.016)$ concentrations, but not with nitrate concentrations $(r=0.014 ; p=0.965)$. This breakdown rate did not significantly change among land-use types (Fig. 4a; $r=0.526 ; p=0.079$ ).

\subsection{Litter breakdown and invertebrates}

No correlation was found between the leaf litter breakdown rate in coarse mesh bags $\left(k_{\mathrm{c}}\right)$ and nutrient concentrations $(r<0.552$; $p>0.0625)$. However, we observed a significant decrease of $k_{c}$ among sites based on anthropogenic disturbances (Fig. 4; $r=749$; $p=0.005): k_{c}$ decreased by $75 \%$ between the reference forested site (i.e. H1) and the most disturbed sites (i.e. JUM).

We did not find any correlations between $k_{\mathrm{c}}$ and the mean richness $(r=0.119 ; p=0.713)$, abundance $(r=0.007 ; p=0.983)$, or with the Simpson dominance index $(r=0.238 ; p=0.457)$ of invertebrates in the litter bags. No significant correlations were found between $k_{\mathrm{c}}$ and the mean taxonomic richness of shredders,

Table 3

Taxonomic richness and abundance of invertebrates in coarse mesh litter bags according to the four site groupings $(\mathrm{F}=$ Forest; $\mathrm{HF}=$ Hedged Farmland $\mathrm{IA}=$ Intensive Agriculture; $\mathrm{IA}+\mathrm{WW}=$ Intensive Agriculture + Waste Water). Pvalues refer to Spearman rank correlations between leaf litter breakdown rates in coarse mesh bags $\left(k_{\mathrm{c}}\right)$ and invertebrate metrics.

\begin{tabular}{|c|c|c|c|c|c|}
\hline & $\mathrm{F}, n=9$ & HF, $n=27$ & IA, $n=27$ & $\begin{array}{l}\mathrm{IA}+\mathrm{WW} \\
n=36\end{array}$ & $P$-values \\
\hline Total richness & $6.3 \pm 2.6$ & $13.6 \pm 4.1$ & $17.3 \pm 5.2$ & $13.8 \pm 4.9$ & NS \\
\hline Total abundance & $67 \pm 29$ & $157 \pm 164$ & $104 \pm 49$ & $141 \pm 77$ & NS \\
\hline Shredder richness & $3.0 \pm 1.2$ & $4.9 \pm 2.1$ & $6.4 \pm 1.8$ & $4.4 \pm 2.5$ & NS \\
\hline Shredder abundance & $62 \pm 28$ & $53 \pm 28$ & $45 \pm 24$ & $24 \pm 23$ & $<0.001$ \\
\hline Scraper richness & $1.7 \pm 1.4$ & $3.6 \pm 2.2$ & $4.1 \pm 2.1$ & $2.9 \pm 1.3$ & NS \\
\hline Scraper abundance & $2.2 \pm 1.9$ & $37 \pm 31$ & $44 \pm 40$ & $83 \pm 60$ & NS \\
\hline $\begin{array}{l}\text { Deposit-feeder } \\
\text { richness }\end{array}$ & $0.9 \pm 0.6$ & $1.2 \pm 1.1$ & $1.9 \pm 1.4$ & $1.9 \pm 0.7$ & NS \\
\hline $\begin{array}{l}\text { Deposit-feeder } \\
\text { abundance }\end{array}$ & $1.4 \pm 1.3$ & $2.8 \pm 3.5$ & $4.1 \pm 4.0$ & $22 \pm 19$ & NS \\
\hline
\end{tabular}


and the mean taxonomic richness and abundance of deposit feeders and scrapers (Table 3; $r<0.454 ; p>0.138$ ). However, $k_{\mathrm{c}}$ was significantly and positively correlated with the mean abundance of shredders in litter bags $(r=0.84 ; p<0.001)$, which significantly decreased from the forested site to the most disturbed type of stations with $62 \pm 28$ and $24 \pm 23$ individuals per bag (Table 3; Kruskal-Wallis test; $N=108 ; p<0.001)$.

The biomass of Gammaridae (here a mix of Gammarus pulex and Echinogammarus berilloni) sampled in the litter bags was highly and positively correlated with breakdown rates in coarse mesh bags (Fig. $5 \mathrm{a} ; r=0.741 ; p<0.006$ ), whereas no relationships were observed with Trichoptera, Plecoptera or total invertebrate biomasses $(r<0.490 ; p>0.11)$. The abundances of Gammaridae in litter bags also decreased from the reference site to the most disturbed sites with $56.2 \pm 15.2$ and $5.8 \pm 2$ individuals per bags, (Fig. 5b; Kruskal-Wallis test; $N=108 ; p<0.001$ ). Similarly, their relative biomass decreased from $85.4 \pm 9.4 \%$ in the forest site to $15.1 \pm 17.9 \%$ in the most disturbed sites (Kruskal-Wallis test; $N=108 ; p<0.001$ ).

The richness and abundance of invertebrates in litter bags and in benthic litter accumulations (i.e. Surber samples) were not correlated with land-use type $(r<0.402 ; p>0.195)$. Richness and Simpson's dominance of invertebrates in litter bags were positively correlated with the richness and dominance in benthic litter accumulations (respectively, $r=0.676 ; p=0.016$ and $r=0.654$; $p=0.029$ ). However, invertebrate abundance in litter bags and in benthic litter was not correlated $(r=0.294 ; p=0.354)$. Gammaridae abundance sampled in the litter bags and benthic litter was highly and positively correlated $(r=0.874 ; p<0.001)$. Furthermore, Gammaridae abundance was negatively correlated with the type of land use $(r=-0.734 ; p=0.006$ for the abundance in litter bags and $r=-0.752 ; p=0.005$ in benthic litter). Among shredders, Gammaridae abundance decreased significantly from the reference site to the most disturbed stations, whereas abundance of most Trichoptera [mainly Mystacides azurea (Leptoceridae) and Lasiocephala basalis (Lepidostomatidae)] increased (Table 4).
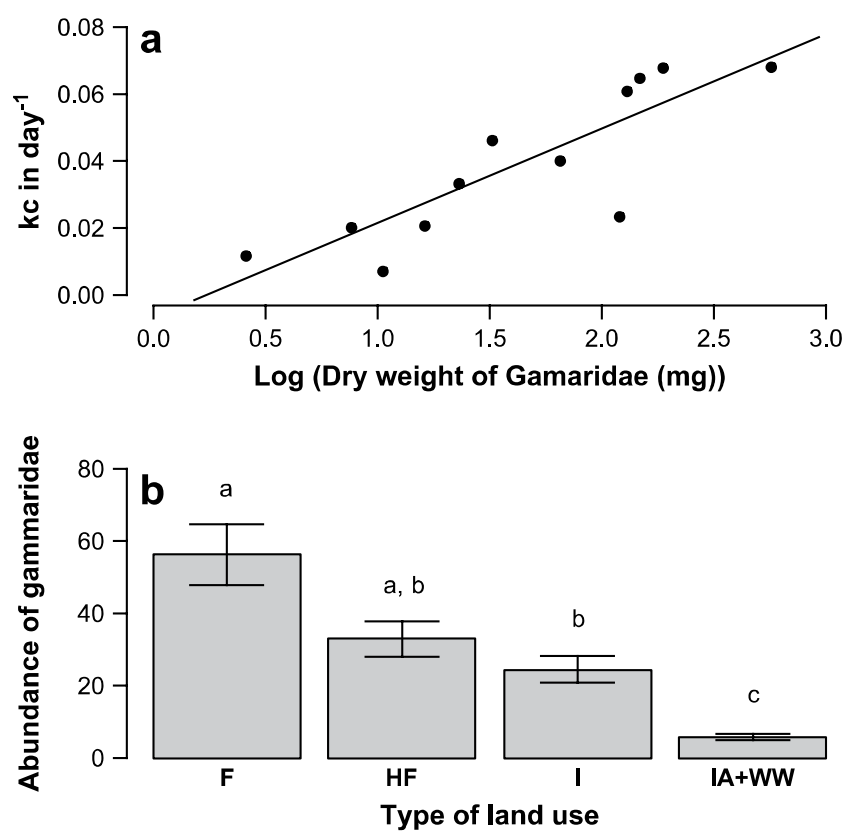

Fig. 5. (a) Relationship between the mean biomass of Gammaridae (log 10-transformed) in each site and the leaf litter breakdown rates in coarse mesh bags $\left(k_{\mathrm{c}}\right)$ $\left(R^{2}=0.72, y=0.028 x-0.007, p<5 \times 10^{-4}\right)$. (b) Average abundance (mean $\pm \mathrm{SE}$ ) of Gammaridae for the different types of land use $(\mathrm{F}=$ Forest; $\mathrm{HF}=$ Hedged farmland; $\mathrm{IA}=$ Intensive agriculture; $\mathrm{IA}+\mathrm{WW}=$ Intensive agriculture plus waste water). For each type, significant between-type differences (multiple comparison tests following the Kruskal-Wallis) in breakdown rates are indicated by different letters.

\section{Discussion}

In this study, we observed a strong upstream-downstream gradient in nutrient concentration of stream water, partly due to agricultural intensification (for nitrate, already highlighted by several works: e.g. Watzin and McIntosh, 1999; Bramley and Roth, 2002; Gergel et al., 2002; Huryn et al., 2002; Roy et al., 2003), but also linked to waste water outflows of villages and industrial farming (for $\mathrm{N}-\mathrm{NH}_{4}^{+}, \mathrm{N}-\mathrm{NO}_{2}^{-}$, and P-SRP; already documented by Xia et al., 2002; see also Brainwood et al., 2004, for farmland waste waters). Released $\mathrm{N}-\mathrm{NH}_{4}^{+}$and $\mathrm{N}-\mathrm{NO}_{2}^{-}$probably decreased through nitrification, which contributed in part to increased nitrate concentrations downstream. In addition to this general trend, we observed strong temporal variability in nutrient concentrations, emphasizing that chemical characteristics are variable and difficult to rely on for assessing the quality of agricultural streams. In such cases, biological processes may be of greater use than water chemical characteristics per se.

\subsection{Microbial processes}

The hydrolasic activity of bottom sediment as determined by FDA hydrolysis did not change between the four land-use types. This activity was significantly correlated with the total organic matter content of the sediments and point-source pollutions as a result of the villages and industrial farming (here the $\mathrm{N}-\mathrm{NH}_{4}^{+}, \mathrm{N}-$ $\mathrm{NO}_{2}^{-}$, and P-SRP concentrations). The latter observation supported our first prediction concerning the increase of microbial heterotrophic activities through an increase in nutrient availability. The enhancement of microbial activities by increased nutrient availability is well documented (e.g. Brookes et al., 2000; MutukuMathooko et al., 2002). Furthermore, hydrolasic activity is known to be strongly linked to the available organic matter in bottom sediments (Marmonier et al., 1995; Claret et al., 1998) and to the exchanges between surface and interstitial waters (Claret et al., 2001). In this study, the hydrolasic activity is thus more closely related to characteristics at a local scale than to large-scale agricultural patterns.

When large invertebrates were not present from litter bags (i.e. in fine mesh bags), we did not observe significant changes in litter breakdown rates due to microbial and meiofauna activities $\left(k_{\mathrm{f}}\right)$ with the types of stations, but strong negative relationships between $k_{\mathrm{f}}$ and $\mathrm{N}-\mathrm{NH}_{4}^{+}, \mathrm{N}-\mathrm{NO}_{2}^{-}$, and P-SRP concentrations (i.e. in relation with the local context of villages and industrial farming). This result is not consistent with our first hypothesis and other studies that highlighted significant increases in microbial biomass and activity together with increasing nutrient contents in stream located in poorly disturbed or pristine rivers (Suberkropp and Chauvet, 1995; Tank and Webster, 1998; Tank and Dodds, 2003) or impacted by waste water inputs where microbial decomposers were poorly affected (Lecerf et al., 2006). In our case, the extremely high values of $\mathrm{N}-\mathrm{NO}_{2}^{-}$and $\mathrm{N}-\mathrm{NH}_{4}^{+}$measured in the most disturbed stations (mean values of $0.035 \mathrm{mg} \mathrm{N}^{-1}$ and $0.109 \mathrm{mg} \mathrm{N}^{-1}$ respectively, see Table 2) may have reached inhibitive thresholds for this heterotrophic process (e.g. Baldy et al., 2007).

In the same way, we did not observe any significant relationships between nitrate concentrations and $k_{\mathrm{f}}$, while Suberkropp and Chauvet (1995) and Huryn et al. (2002) highlighted a positive correlation. This apparent contradiction may be linked to the strong degradation of surface and ground waters in Brittany (French Water Agency, http://www.eau-loire-bretagne.fr/) and the very high nitrate concentrations in our most disturbed stations (up to $19.0 \mathrm{mg} \mathrm{Nl}^{-1}$, Table 2), that are well above those reported from other studies (e.g. concentrations always lower than $0.8 \mathrm{mg} \mathrm{N}^{-1}$ in Huryn et al., 2002). In addition, high nitrate concentrations were associated with high $\mathrm{N}-\mathrm{NH}_{4}^{+}$and $\mathrm{N}_{-} \mathrm{NO}_{2}^{-}$concentrations. A positive 
Table 4

Correlation between land-use types and abundances of the main taxonomic groups of shredders associated with benthic litter accumulations $(\mathrm{F}=\mathrm{Forest}$; $\mathrm{HF}=\mathrm{Hedged}$ Farmland; IA = Intensive Agriculture; IA + WW = Intensive Agriculture + Waste Water). $P$-values refer to Spearman rank correlations between invertebrate metrics and the type of land use.

\begin{tabular}{|c|c|c|c|c|c|c|c|}
\hline & & $\mathrm{F}, n=4$ & HF, $n=12$ & IA, $n=12$ & $\mathrm{IA}+\mathrm{WW}, n=16$ & Spearman $R$ & $P$ \\
\hline \multirow[t]{2}{*}{ Crustacea } & Asellidae & $2 \pm 2$ & $9.3 \pm 9$ & $2.9 \pm 5$ & $7.5 \pm 11$ & - & NS \\
\hline & Gammaridae & $313 \pm 160$ & $92 \pm 67$ & $122 \pm 89$ & $23 \pm 25$ & -0.66 & $<0.001$ \\
\hline Diptera & & 0 & $0.2 \pm 0$ & $0.4 \pm 1$ & $0.3 \pm 0$ & - & NS \\
\hline Plecoptera & & 0 & $5.8 \pm 8$ & $0.4 \pm 1$ & $0.3 \pm 1$ & - & NS \\
\hline \multirow[t]{3}{*}{ Trichoptera } & Leptoceridae & 0 & 0 & $3.3 \pm 6$ & $3.9 \pm 8$ & 0.32 & 0.029 \\
\hline & Limnephilidae & $54 \pm 13$ & $32 \pm 24$ & $22 \pm 25$ & $32 \pm 25$ & - & NS \\
\hline & Others & $11.5 \pm 5$ & $2.6 \pm 3$ & $13.3 \pm 9$ & $49 \pm 71$ & 0.53 & $<0.001$ \\
\hline
\end{tabular}

linear relationship between nitrate and $k_{\mathrm{f}}$ [as observed by Suberkropp and Chauvet, 1995] may have been masked by the inhibiting effect of $\mathrm{N}_{-} \mathrm{NH}_{4}^{+}, \mathrm{N}-\mathrm{NO}_{2}^{-}$and/or xenobiotics (e.g. Fungicides) in our most perturbed sites. Such antagonistic effects as suspected in the present study may result in a non-linear response of $k_{\mathrm{f}}$ to a broad range of anthropogenic pressures, which complicate the use of microbial breakdown rate as an indicator of agricultural stream ecosystem impairment.

\subsection{Litter breakdown and invertebrates}

In contrast to processes linked to microbial and meiofaunal activities, we observed no relationships between litter breakdown rates in coarse mesh bags $\left(k_{c}\right)$ and local chemical characteristics, but strong differences of $k_{\mathrm{c}}$ among land-use types (with a decrease by $75 \%$ between the reference and the most disturbed stations). This result supports our second prediction that agricultural practices would result in negative effects on invertebrates, and in particular on shredders. The decreasing rate of litter breakdown with increasing agricultural intensity was indeed significantly correlated with a decrease in shredder abundance (supporting our fourth prediction). Several studies have related breakdown rates to the shredder density or biomass (Benfield and Webster, 1985; Fabre and Chauvet, 1998; Niyogi et al., 2001; Huryn et al., 2002) and highlighted the role of shredders in controlling litter breakdown in different land-use contexts including agricultural areas (Lecerf et al., 2006; Hagen et al., 2006). For example, Sponseller and Benfield (2001) found that breakdown rates of sycamore leaves were correlated with shredder biomass related to streambed particle size and to the land use in the surrounding catchment.

In this study, the breakdown rate was correlated with the shredder biomass and abundance in accord with our fourth prediction, but not with shredder taxonomic richness (in contradiction with our third prediction and findings of Huryn et al., 2002). Among shredders, only the biomass of Gammaridae was significantly correlated with breakdown rates. These two results suggest that there is no functional redundancy in the litter consumption among shredder species in the studied streams and the decrease of Gammaridae along the gradient of land use was not compensated for by the activity of other taxonomic groups. Gammaridae hence appears as the key species for the leaf litter breakdown processes in these rural streams. However, the per capita efficiency of Gammaridae appears low relative to other shredders (Jonsson et al., 2002). This implies that freshwater amphipods control leaf litter breakdown, and indirectly the diversity-function relationship, primarily through their high abundance (they represented $85 \%$ of the invertebrate community at the reference site) rather than by high-energy conversion efficiency. This hypothesis is supported by the observed decrease in $k_{\mathrm{c}}$ and Gammaridae abundances with agricultural intensification in both litter bags (Fig. 4) and benthic litter accumulations (Table 4). Sensitivity of Gammaridae to nutrient concentrations was experimentally demonstrated for nitrate (Camargo et al., 2005), nitrite (Alonso and Camargo, 2006), and phosphorus (McCormick et al., 2004), all being strongly associated with anthropogenic disturbances (i.e. agricultural practices like industrial farming).

The abundance and diversity of invertebrates in litter bags were highly correlated with those in benthic litter accumulations. The impact of agricultural practices is thus similar for assemblages sampled in the litter bags and in the benthic habitat. However, we observed in benthic litter accumulations an increase of some Trichoptera (mainly $M$. azurea and $L$. basalis) not observed in litter bags. M. azurea fed on living macrophyte (Tachet et al., 2000), which tend to increase with increasing agriculture in Brittany (Haury and Aiddara, 1999). The increase in the abundance of $L$. basalis is difficult to explain because of the sensitivity of this species to high nutrient concentrations (Bonada et al., 2004). A possible explanation might be the observed decrease in Gammaridae, which may result in changes in the assemblage composition as already observed in other rural streams in Brittany (Sarriquet et al., 2007).

\section{Conclusion}

In conclusion, our study suggests that microbial processes are strongly influenced by microhabitat conditions, and thus are ineffective indicators of agricultural disturbances. In contrast, the total litter breakdown (as represented by $k_{\mathrm{c}}$ ) may be an efficient tool to evaluate the effect of anthropogenic disturbances occurring at the catchment scale, e.g. linked to the agricultural intensification. Here, the values of $k_{\mathrm{c}}$ were strongly controlled by one group of shredders, the Gammaridae, which can be considered as the key organisms controlling litter breakdown. In addition, redundancy among shredder species was absent or very weak in the studied streams. The hypothesis of Huryn et al. (2002) that an assemblage of species sensitive to disturbance can be functionally replaced by an assemblage of organisms more tolerant to declining water quality is thus not supported by our results in the Brittany streams. The lack of functional redundancy (Covich et al., 1999; Mermillod-Blondin et al., 2001) in this agricultural area may be a major factor that induces dysfunctioning of heterotrophic processes in streams affected by intense agriculture. As a result, future work should focus on the efficiency of rare species in controlling litter breakdown in sites where Gammaridae are excluded for other reasons (e.g. in temporary streams).

\section{Acknowledgements}

We are grateful to Marie-Paule Briand and Nathalie Josselin for their technical help. We thank Leah Beche for linguistic advices and the two anonymous referees for their helpful comments on the manuscript. This study was supported by the DIVA programme of the French Ministry of Ecology and Sustainable Development, the PAPIER project of the ECosphére COntinentale 2005 programme and the InBioProcess project of the Biodiversity 2006 programme of the French National Research Agency (Agence Nationale de la Recherche, ANR). 


\section{References}

Ainsworth, W., Goulder, R., 2000. The effects of sewage-works effluent on riverine extracellular aminopeptidase activity and microbial leucine assimilation. Water Research 34, 2551-2557.

Allan, J.D., 2004. Landscape and riverscape: the influence of land use on river ecosystems. Annual Reviews of Ecology, Evolution and Systematics 35, 257-284.

Alonso, A., Camargo, J.A., 2006. Toxicity of nitrite to three species of freshwater invertebrates. Environmental Toxicology 21, 90-94.

Amann, R., 2000. Who is out there? Microbial aspects of biodiversity. Systematic and Applied Microbiology 23, 1-8

APHA, 1976. Standard Methods for the Examination of Water and Wastewater. American Public Health Association, New York.

Arheimer, B., Liden, R., 2000. Nitrogen and phosphorous concentrations from agricultural catchments - influence of spatial and temporal variables. Journal of Hydrology 227, 140-159.

Baldy, V., Gobert, V., Guerold, F., Chauvet, E., Lambrigot, D., Charcosset, J.Y., 2007. Leaf litter breakdown budgets in streams of various trophic status and especially the effects of dissolved inorganic nutrients on microorganisms and invertebrates. Freshwater Biology 52, 1322-1335.

Barnes, H., Kollard, A.R., 1951. The Determination of Nitrite. National Council for Exploration of the Sea, Charlottenland.

Battin, T.J., 1997. Assessment of fluorescein diacetate hydrolysis as a measure of total esterase activity in natural stream sediment biofilms. Science of the Total Environment 198, 51-60.

Benfield, E.F., Webster, J.R., 1985. Shredder abundance and leaf breakdown in an Appalachian Mountain stream. Freshwater Biology 15, 113-120.

Bonada, N., Zamora-Munoz, C., Rieradevall, M., Prat, N., 2004. Ecological profiles of caddisfly larvae in Mediterranean streams: implications for bioassessment methods. Environmental Pollution 132, 509-521.

Boulton, A.J., Boon, P.I., 1991. A review of methodology used to measure leaf litter decomposition in lotic environments: time to turn over an old leaf? Australian Journal of Marine and Freshwater Research 42,1-43.

Brainwood, M.A., Burgin, S., Maheshwari, B., 2004. Temporal variations in water quality of farm dams: impacts of land use and water sources. Agricultural Water Management 70, 151-175.

Bramley, R.G.V., Roth, C.H., 2002. Land-use effects on water quality in an intensively managed catchments in the Australian humid tropics. Marine and Freshwater Research 53, 931-940.

Bretschhko, G., Leichtfried, M., 1988. Distribution of organic matter and fauna in a second order, alpine gravel stream (Ritrodat-Lunz study area, Austria). Verhandlunden der Internationalen Vereinigung für Theoritische und Angewandte Limnologie 23, 1333-1339.

Brookes, J.D., Geary, S.M., Ganf, G.G., Burch, M.D., 2000. Use of FDA and flow cytometry to assess metabolic activity as an indicator of nutrient status in phytoplankton. Marine and Freshwater Research 51, 817-823.

Burel, F., Butet, A., Delettre, Y.R., Millan de la Pena, N., 2003. Differential response of selected taxa to landscape context and agricultural intensification. Landscape Urban Planning 1018, 1-10.

Camargo, J.A., Alonso, A., Salamanca, A., 2005. Nitrate toxicity to aquatic animals: a review with new data for freshwater invertebrates. Chemosphere 58, 1255-1267.

Castillo, M.M., Allan, J.D., Brunzell, S., 2000. Nutrient concentrations and discharges in a Midwestern agricultural catchment. Journal of Environmental Quality 29, $1142-1151$.

Chauvet, E., 1987. Changes in the chemical composition of alder, poplar and willow leaves during decomposition in a river. Hydrobiologia 148, 35-44.

Claret, C., Marmonier, P., Bravard, J.P., 1998. Seasonal dynamics of nutrients and biofilms in interstitial habitats in two contrasting riffles in a regulated large river. Aquatic Sciences 60, 33-55.

Claret, C., Boulton, A.J., Dole-Olivier, M.J., Marmonier, P., 2001. Functional processes versus state variables: interstitial organic matter and breakdown pathways in floodplain habitats varying in groundwater input and sediment size. Canadian Journal of Fisheries and Aquatic Sciences 58, 1594-1602.

Corkum, L.D., 1996. Responses of chlorophyll-a, organic matter, and macroinvertebrates to nutrient additions in rivers flowing through agricultural and forested land. Archiv für Hydrobiologie 136, 391-411.

Covich, A.P., Palmer, M.A., Crowl, T.A., 1999. The role of benthic invertebrate species in freshwater ecosystems. BioScience 49, 119-127.

Dolédec, S., Philips, N., Scarsbrook, M.R., Riley, R.H., Townsend, C.R., 2006. A comparison of structural and functional approaches to determining land-use effects on grassland stream invertebrate communities. Journal of the North American Benthological Society 25, 44-60.

Eisman, F., Montuelle, B., 1999. Microbial methods for assessing contaminant effects in sediment. Review of Environmental Contamination and Toxicology 159, 41-93.

Fabre, E., Chauvet, E., 1998. Leaf breakdown along an altitudinal stream gradient. Archiv für Hydrobiologie 141, 167-179.

Findlay, S., Quinn, J.M., Hickey, C.W., Burrell, G., Downes, M., 2001. Effects of land use and riparian flowpath on delivery of dissolved organic carbon to streams. Limnology and Oceanography 46, 354-355.

Fisher, D.S., Steiner, J.L., Endale, D.M., Stuedemann, J.A., Schomberg, H.H., Franzluebbers, A.J., Wilkinson, S.R., 2000. The relationship of land use practices to surface water quality in the upper Oconee watershed of Georgia. Forest Ecological Management 128, 39-48.
Fontvieille, D., Outaguerouine, A., Thevenot, D.R., 1992. Fluorescein diacetate hydrolysis as a measure of microbial activity in aquatic systems: application to activated sludges. Environmental Technology 13, 531-540.

Gergel, S.E., Turner, M.G., Miller, J.R., Melack, J.M., Stanley, E.H., 2002. Landscape indicators of human impacts to riverine systems. Aquatic Sciences 64, 118128

Gessner, M.O., Chauvet, E., 2002. A case for using litter breakdown to assess functional stream integrity. Ecological Applications 12, 498-510.

Goolsby, D.A., Battaglin, W.A., Aulenbach, B.T., Hooper, R.P., 2000. Nitrogen flux and sources in the Mississippi River basin. Science of the Total Environment 248, $75-86$

Hagen, E.M., Webster, J.R., Benfield, E.F., 2006. Are leaf breakdown rates a useful measure of stream integrity along an agricultural landuse gradient? Journal of the North American Benthological Association 25, 330-343.

Harding, J.S., Benfield, E.F., Bolstad, P.V., Helfman, G.S., Jones, E.B.D., 1998. Stream biodiversity: the ghost of land use past. Proceedings of the National Academy of Sciences of the USA 95, 14843-14847.

Haury, J., Aïdara, L.G., 1999. Macrophyte cover and standing crop in the river Scorfff and its tributaries (Brittany, norhtwestern France): scale, patterns and process. Hydrobiologia 415, 109-115.

Huryn, A.D., Butz Huryn, V.M., Arbuckle, C.J., Tsomides, L., 2002. Catchment landuse, macroinvertebrates and detritus processing in headwater streams: taxonomic richness versus function. Freshwater Biology 47, 401-415.

Hynes, H.B.N., 1960. The Biology of Polluted Waters. Liverpool University Press, Liverpool.

Ihaka, R., Gentleman, R., 1996. R: a language for data analysis and graphics. Journal of Computational and Graphical Statistics 5, 299-314.

Jonsson, M., Dangles, O., Malmqvist, B., Guérold, F., 2002. Simulating species loss following disturbance: assessing the effects on process rates. Proceedings of the Royal Society of London Series B 269, 1047-1052.

Lecerf, A., Usseglio-Polatera, P., Charcosset, J.-Y., Lambrigot, D., Bracht, B., Chauvet, E., 2006. Assessment of functional integrity of eutrophic streams using litter breakdown and benthic macroinvertebrates. Archiv für Hydrobiologie $165,105-126$.

Magurran, A.E., 1988. Ecological Diversity and its Measurement. Princeton University Press, Princeton.

Marmonier, P., Fontvieille, D., Gibert, J., Vanek, V., 1995. Distribution of dissolved organic carbon and bacteria at the interface between the Rhône River and its alluvial aquifer. Journal of the North American Benthological Society 14, 382-392.

McCormick, P.V., Shuford, R.B.E., Rawlik, P.S., 2004. Changes in macroinvertebrate community structure and function along a phosphorus gradient in the Florida Everglades. Hydrobiologia 529, 113-132.

Mermillod-Blondin, F., Gérino, M., Degrange, V., Lensi, R., Chassé, J.L., Rard, M., Creuzé des Châtelliers, M., 2001. Testing the functional redundancy of Limnodrilus and Tubifex (Oligochaeta, Tubificidae) in hyporheic sediments: an experimental study in microcosms. Canadian Journal of Fisheries and Aquatic Sciences 58, 1747-1759.

Meybeck, M., 1982. Carbon, nitrogen, and phosphorus transport by world rivers. American Journal of Science 282, 401-450.

Montreuil, O., Mérot, P., 2006. Nitrogen removal in valley bottom wetlands: assessment in headwater catchments distributed throughout a large basin. Journal of Environmental Quality 35, 2113-2122.

Montuelle, B., Volat, B., 1998. Impact of wastewater treatment plant discharge on enzyme activity in freshwater sediment. Ecotoxicology and Environmental Safety 40, 154-159.

Murphy, J., Riley, J.P., 1962. A modified single-solution for the determination of phosphate in natural waters. Annual Chemical Acta 27, 31-36.

Mutuku-Mathooko, J., Kemuma Mokaya, S., Leichtfried, M., 2002. Characterization of sediment biofilms in stressed sites in a lotic ecosystem in the Rift Valley Province, Kenya. Hydrobiologia 489, 1-10.

Niyogi, D.K., Lewis, W.M., McKnight, D.M., 2001. Litter breakdown in mountain streams affected by mine drainage: biotic mediation of abiotic controls. Ecological Applications 11, 506-516

Ometo, J.P.H.B., Martinelli, L.A. Ballester, M.V., Gessner, A., Krusche, A.V., Victoria, R.L., Williams, M., 2000. Effects of land-use on water chemistry and macroinvertebrates in two streams of the Piracicaba river basin, South-east Brazil. Freshwater Biology 44, 327-337.

Petersen, R.C., Cummins, K.W., 1974. Leaf processing in a woodland stream. Freshwater Biology 4, 343-368.

Randall, G.W., Mulla, D.J., 2001. Nitrate Nitrogen in surface waters as influenced by climatic conditions and agricultural practices. Journal of Environmental Quality 30, 337-344.

Romesburg, H.C., 1985. Exploring, confirming and randomization tests. Computer and Geosciences 11, 19-37.

Rossum, J.R., Villaruz, P.A., 1963. Determination of ammonia by the indophenol method. Journal of the American Water Works Association 55, 657

Roy, A.H., Rosemond, A.D., Leigh, D.S., Paul, M.J., Wallace, J.B., 2003. Habitat-specific responses of stream insects to land cover disturbance: biological consequences and monitoring implications. Journal of the North American Benthological Society 22, 292-307.

Sarriquet, P.E., Delettre, Y., Marmonier, P., 2006. Effects of catchment disturbance on stream invertebrates: comparison of different habitats (vegetation, benthic and interstitial) using bio-ecological groups. International Journal of Limnology 42 , 205-219.

Sarriquet, P.E., Bordenave, P., Marmonier, P., 2007. Effects of bottom sediment restoration on interstitial habitat characteristics and benthic macroinvertebrate 
assemblages in a headwater stream. River Research and Applications 23, 815-828.

Schnurer, J., Rosswall, T., 1982. Fluorescein diacetate hydrolysis as a measure of total activity in soil and litter. Applied Environmental Microbiology 43, 1256-1261.

Siegel, S., Castellan, N.J., 1988. Nonparametric Statistics for the Behavioural sciences, second ed. McGraw-Hill, New York.

Sponseller, R.A. Benfield, E.F, 2001. Influences of land use on leaf breakdown in southern Appalachian headwater streams: a multi-scale analysis. Journal of the North American Benthological Society 21, 97-113.

StatSoft, 2001. STATISTICA (data analysis software system). Version 6. www.statsoft.com. Suberkropp, K., Chauvet, E., 1995. Regulation of leaf breakdown by fungi in streams influences of water chemistry. Ecology 76, 1433-1445.

Tachet, H., Richoux, P., Bournaud, M., Usseglio-Polatera, P., 2000. Invertébrés d'eau douce: systématique. biologie et écologie. CNRS édition, Paris.

Tank, J.L., Dodds, W.K., 2003. Nutrient limitation of epilithic and epixylic biofilms in ten North American streams. Freshwater Biology 48, 1031-1049.
Tank, J.L., Webster, J.R., 1998. Interaction of substrate and nutrient availability on wood biofilm processes in streams. Ecology 79, 2168-2179.

Townsend, C.R., Downes, B.J., Peacock, K., Arbuckle, C.J., 2004. Scale and the vegetation of land-use effects on morphology, vegetation and macroinvertebrate communities of grassland streams. Freshwater Biology 49, 448-462.

Vitousek, P.M., Aber, J.D., Howarth, R.W., Likens, G.E., Matson, P.A., Schindler, D.W. Schlesinger, W.H., Tilman, D.G. 1997. Human alteration of the global nitrogen cycle: Sources and consequences. Ecological Applications 7 , 737-750.

Watzin, M.C., McIntosh, A.W., 1999. Aquatic ecosystems in agricultural landscapes: a review of ecological indicators and achievable ecological outcomes. Journal of Soil and Water Conservation 54, 636-644.

Xia, X., Zhou, J.S., Yang, Z.F., 2002. Nitrogen contamination in the Yellow River basin of China. Journal of Environmental Quality 31, 917-925.

Young, R.G., Huryn, A.D., 1999. Effects of land use on stream metabolism and organic matter turnover. Ecological Applications 9, 1359-1376. 